\title{
Leukonychia totalis
}

INSERM

\section{Source}

INSERM. (1999). Orphanet: an online rare disease and orphan drug data base.

Leukonychia totalis. ORPHA:2387

Leukonychia totalis is a rare nail anomaly disorder characterized by complete white discoloration of the nails. Patients typically present white, chalky nails as an isolated finding, although other cutaneous or systemic manifestations could also be present. 